\title{
A Study on the Validity of the English Learning Style Scale for Korean High School Students in a Native Teacher's Class Based on Multimedia*
}

\begin{abstract}
Kim, Nayu · Lee, Heechul ${ }^{* *}$
(Chonbuk National University)

Kim, Nayu \& Lee, Heechul. (2018). A study on the validity of the English learning style scale for Korean high school students in a native teacher's class based on multimedia. STEM Journal, 19(4), 149-165.

The purpose of this study is to investigate the characteristics of English learning styles of students who participated in a native speaker's English class based on multimedia. To achieve this goal, one hundred and four high school students took part in this study and responded to a questionnaire surveying their English learning styles. A factor analysis was conducted based on students' responses, and five English learning styles were extracted. In the native speaker's class, students were found to have a class immersion style, focusing actively on the class procedure with higher self-confidence, a self-expression style, wanting to show their own thoughts and expressions, a goal recognition style, focusing on recognition and performance of clear goals, a systematic dependence style, expecting clear teaching and evaluation methods, and an information orientation style, actively collecting and using information learned in class. Reflecting on these learning styles, English teachers and co-teachers should prepare creative learning materials based on a systematic lesson plan for students to be absorbed in the class and to participate in class with self-efficacy. In addition, the teacher should consider ways in which students gather and use information related to the topic of the lesson and provide enough opportunities for students to speak in English.
\end{abstract}

\section{INTRODUCTION}

Under the second language acquisition (SLA) circumstance, Auerbach (1993) argued

\footnotetext{
* This research was supported by "Research Base Construction Fund Support Program" funded by Chonbuk National University in 2018.

${ }^{* *} 1$ st author: Kim, Nayu; Corresponding author: Lee, Heechul
} 
that a native speaker was one of the critical components of English learning, and that the target language should be used as much as possible with a native speaker. In addition, it is almost common sense that teaching students English in English in the English as a Foreign Language (EFL) circumstance is ideal (Brown, 2000). The use of a target language in English classroom allows learners to become familiar with English and to increase their confidence in their ability to use foreign language in various situations (Rosenthal \& Robert, 1984). Considering these points, the government of Korea has tried for Korean English teachers to carry out the English class in English sequentially from an elementary school to a high school from 2001, and invested a lot of budget in training of teachers and the construction of "English Village" (Kim, 2010). English Village is a space created by an artificial environment that uses English authentically so that students learn English in real conditions. In addition, there have been various studies on a native speaker's English class in line with these trends, and most of them have shown that students' English proficiency, interest, and self-confidence have increased in the class with a native speaker (Kim \& Jeong, 2008).

However, despite these steady researches, there are few studies that focus on the English learning styles of students who are taught English by a native speaker. Students participate in classes of a native English teacher and have a specific learning style. It is clear that students maintain a distinctive learning style in that it is not relatively frequent to experience a native English teacher's class and students do not have to devote to learning to score. In particular, due to the development of multimedia and the wide application of audiovisual classes, a native English teacher's class are undergoing major changes. Unlike the past classes that focused on a simple English conversation, a native speaker is now approaching students with a variety of multimedia. In addition, the Internet environment and the use of smart devices, which have become much better than in the past, have had a significant impact on students' perceptions of an English class. Students get the information quickly and easily they want, talk to their teacher about learning from time to time, and check their learning achievement frequently. Taking all of these into consideration, it is important to study the validity of the scale for understanding the English learning style of the students participating in the multimedia-based English class of a native English teacher.

Considering these changes, it is important to analyze how the students' perceptions of English learning have changed and what kinds of learning styles they have had by the class of a native speaker based on multimedia. Including how to use the students' learning styles to enhance a native teacher's class, specific research questions in this study were set up as followed: 1) What are the characteristics of English learning styles that students have in a native English teacher's class based on multimedia? 2) What are the ways to improve 
a native speaker's class by taking advantage of these learning styles?

\section{THEORETICAL BACKGROUNDS}

\section{A Native Speaker and English Class}

Native speakers are people who speak their target language when they are born. An assistant teacher is a person with an instructional capacity who works with a specialist in school and is supervised by a certified or licensed professional who is responsible for the ultimate responsibility and performance of the program (Shim, Lee, \& Eom, 2016). As Li (2005) argued that a native speaker's fluency in his or her target language and free mood drew the attention of the learners, in a study on the characteristics of instructors who teach English in EFL circumstance, he pointed out both the merits and demerits of native and non-native speakers (Kim, Kang, \& Yoon, 2013). Researchers have studied various aspects of the positive impact of a native speaker's English class at elementary, secondary, and university levels. Ryu (2003) conducted a study on the effect of cooperative teaching with a native speaker on elementary school students' emotional areas. In the study, students became more interested in learning English, the feeling of resistance to English use was reduced, and the motivation and self-confidence increased. According to Chae (2007), the cooperative English teaching with a native speaker has a positive effect on middle school students. He reported that students improved their English ability, increased their interest in English, and resolved their fear of English by a native speaker. Yeon (1996) made high school students involved in cooperative English classes with a native teacher, found that students became more interested in English, and that the opportunity to contact a native speaker eliminate students' fear. According to a study of Korean college students who experienced a native speaker and a non-native speaker as a professor by Chun (2015), the learners thought that a native speaker's fluency, natural English ability, and tolerant and free learning atmosphere were the advantages, otherwise lack of knowledge of Korean culture and language were disadvantages. However, there are few specific case studies on the effectiveness of a native speaker's class depending on the educational conditions of the school and the level of English ability of the students (Park, 2011), and it is required to investigate how to effectively utilize a native speaker and lead cooperative classes successfully (Lee \& Seong, 2011; Min, Kim, Rha, \& Kang, 2014). However, in spite of various studies on the use of native teachers, there are few studies on the characteristics of students' attitudes, strategies, and styles in terms of students' cognitive and emotional changes due to the teaching of a native English teacher. 


\section{Multimedia and English Learning}

With the advent of the information age and the increasing interest in an English class using multimedia, various multimedia English learning programs contents are actively in schools. This is because multimedia-based learning programs have diverse characteristics that facilitate language learning (Kim, 2001). Barker and Tucker (1990) defined multimedia as an integrated system of multiple media. On the other hand, Gayeski (1993) emphasized interactivity by defining multimedia as an interactive communication system that is induced by computer for visual and auditory information network. Heinich, Molenda, Russell, and Smaldino (1996) defined multimedia as a combination of two or more media formats. As such, multimedia refers to the integration of various media such as texts, pictures, sounds, graphic images, and video into computers (Looms, 1993). Multimedia has various characteristics that lead to a positive learning effect compared to what is presented simply as a personality (Kim, 2001). First, multimedia facilitates language learning by utilizing various media such as text, sound, and video. In other words, learners are not simply acquiring information through texts, but learning through various media, thereby facilitating the absorption of information (Amthor, 1991). Second, unlike books in which information is linearly arranged, multimedia is composed of nonlinear media such as text, sound, and video, by self-regulation learned individually (Liu \& Reed, 1995). Third, because multimedia use devices such as pictures, video, and sound, it helps learners to understand contents and motivate them to learn English (Davey, Jones, \& Fox, 1995). Fourth, multimedia convey information by recreating the web of semantic relationships similar to the human thinking structure (Perzylo, 1993). Multimedia also serves as a catalyst for learning because it presents old information and new information in a systematic net form. Learner maximize learning effect by linking old information with existing knowledge (Liu \& Reed, 1995). Multimedia provides appropriate feedback on the performance of learners' tasks, which not only facilitates interaction in learning English, but also enhances learning motivation (Lee, 1997). In addition, multimedia works with texts, pictures, photographs, animations, voice and videos, making it possible for learners to get to understand learning contents more vividly and practice English dynamically. In the same vein, today English education uses various technologies such as multimedia and internet. Therefore, English education is completely different from existing teaching forms and methods (Choi, Kim, \& Kim, 2006). Although a variety of studies have been conducted on the impact of multimedia on English education, it has not been well studied how multimedia influences students' characteristics of English learning. In other words, it is necessary to focus on the internal changes of students as well as the external benefits of multimedia. 


\section{Learning Style}

A style is a particular way in which a person accomplishes a task, and refers to an individual's tendency to be consistent and permanent (Brown, 2000). Students use what they learn through learning and memorizing in school outside the school. A style represents a set of self-perceptions when teachers observe special behaviors of students in the classroom (Brown, 2000). In spite of the necessity of individual instruction of learners in English class, its implementation is difficult because the individual learners have different competencies, conditions, cultural backgrounds and various styles of learning (Cho, 2001). Especially, in order to increase the learning effect of the individual, a lesson plan considering the learning style of the student should be designed.

In the respective of learning styles, Kolb (2007) has argued that learning takes place through the process of changing experience and knowledge, and this process is called "concrete experiences", "reflective observation", "abstract conceptualization" and "active experimentation." "Concrete experiences" is a process of sensing and emotional immersion while performing a specific act. "Reflective observation" is a process of looking at concrete experiences. Through this process, the relationship between experience and abstract theory or concept can be understood. In addition, "abstract conceptualization" is the process of integrating theory and concepts into the overall learning process through intensive thinking, and learning with such abstract conceptualization can be called deep learning. Deep learning is to grasp precise principles and essential meanings, to understand facts and feelings, and to achieve the knowledge and integration gained in the past. Kolb (2007) conceptualized the styles of learning of an individual by letting them express their personal preference for these four processes numerically and synthesizing the results. To do this, he developed a learning style checklist that is called the Learning Style Inventory (LSI).

\section{RESEARCH METHODS}

\section{Subjects}

One hundred four students in the second year of high school in Jeollabuk-do participated in the study. Students were taught in the same official English curriculum in 2017, and a native speaker taught them English based on multimedia one hour out of five hours of English class each week. All of the students were male students, living in the same area, and none of them had a long stay in an English-speaking country. In addition, none of the students who took part in the study had received any special English class after school, 
and all students relied on official English classes at school. Considering the results of nationwide English achievement assessment in 2017, the English level of the students who took part in the study was intermediate level, whose score was between about 45 and 75 points.

\section{Procedures}

The students have participated in a native English teacher's class for six months once a week. The class time was 50 minutes and the assistant teacher joined the class with the native English teacher and helped the class on various ways. The lesson plan was prepared in advance with the assistant teacher and revised several times in consideration of the students' English ability and emotional state. The native teacher's class was held as a regular class, not an extracurricular class, and about 25 students participated in each class. The native teacher's class was based on multimedia, and various visual and audible materials were used about American culture and customs. In particular, Youtube video clips or game applications were widely used in the classes. If necessary, the students and teachers communicated using smartphone each other.

\section{Instrument}

In order to investigate the styles of English learning, questionnaire items were designed and used in this study. The questionnaire items were produced based on Kolb's (2007) LSI in Korean. Each item was revised and supplemented to make it easier for high school students to understand, and summarized the items into 20 items focusing on critical contents to meet the purpose of the study. The questionnaire was structured in order to include four stages of empirical learning presented in LSI and tried to be expressed as concise sentences considering the level of cognitive development of students in Korean. A Likert scale, five level, with one point for the most negative response and five points for the most positive response, was applied to each item. Detailed questionnaire items are presented in Table 1.

TABLE 1

Items of Questionnaire

\begin{tabular}{cl}
\hline \hline No. & \multicolumn{1}{c}{ Item } \\
\hline 1 & I like to do my homework without helping others. \\
2 & I want the teacher to tell me exactly what you expect from your class. \\
3 & I think my personal opinion on the content is as good as textbooks. \\
4 & I ask the teacher when I judge the importance of the learning contents. \\
5 & I am studying the content that is important to me first, and I think that the contents of the \\
& teacher's class are always important.
\end{tabular}


A Study on the Validity of the English Learning Style Scale for Korean High School Students in a Native Teacher's Class Based on Multimedia

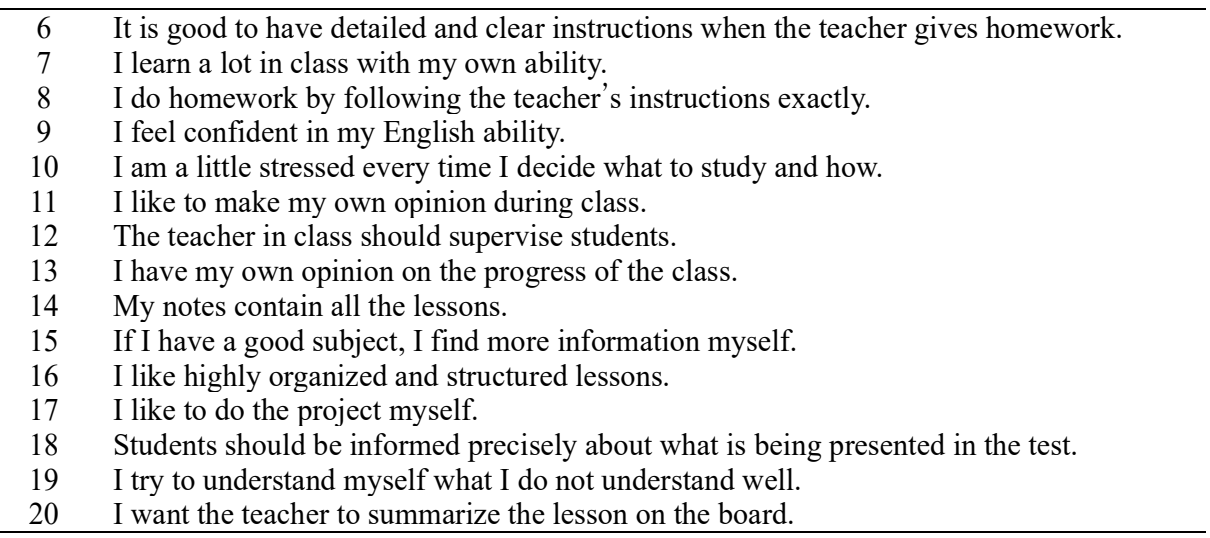

\section{Data Analysis}

The results of the students' responses were analyzed by the SPSS 20.0 program. The principal component analysis was performed by inputting the results of each item as variables. Principal component analysis is a factor analysis method that is used to reduce the number of factors existing among the variables to as few as possible while minimizing the loss of information (Hair, Black, Babin, \& Anderson, 2010). Since factor analysis is one that identifies the correlation between variables, variables should be entered as interval scales. In this study, the questionnaire items were designed as the Likert scales to do this. The characteristics of English learning styles of subjects in this study have been extracted and analyzed.

\section{RESULT AND DISCUSSIONS}

\section{Descriptive Statistics and Item Reliability}

The mean values and standard deviation ones of each item are presented in Table 2. The item with the smallest mean value was item 12 'Students should be supervised by the teacher in class' (2.86), and the item with the largest mean value was item 18 'Students should be informed precisely about what is being presented in the test' (3.88). The lowest standard deviation value was item 2 and the highest standard deviation value was item 12 (1.024). 
TABLE 2

Descriptive Statistics

\begin{tabular}{cccccc}
\hline \hline Item & $N$ & Min. & Max. & $M$ & $S D$ \\
\hline 1 & 104 & 1.00 & 5.00 & 3.63 & .788 \\
2 & 104 & 2.00 & 5.00 & 3.80 & .683 \\
3 & 104 & 2.00 & 5.00 & 3.51 & .824 \\
4 & 104 & 2.00 & 5.00 & 3.28 & .931 \\
5 & 104 & 2.00 & 5.00 & 3.73 & .838 \\
6 & 104 & 1.00 & 5.00 & 3.84 & .952 \\
7 & 104 & 1.00 & 5.00 & 3.23 & .894 \\
8 & 104 & 1.00 & 5.00 & 3.75 & .833 \\
9 & 104 & 1.00 & 5.00 & 3.51 & .955 \\
10 & 104 & 1.00 & 5.00 & 3.71 & .991 \\
11 & 104 & 2.00 & 5.00 & 3.53 & .695 \\
12 & 104 & 1.00 & 5.00 & 2.86 & 1.024 \\
13 & 104 & 2.00 & 5.00 & 3.63 & .711 \\
14 & 104 & 1.00 & 5.00 & 2.90 & .950 \\
15 & 104 & 1.00 & 5.00 & 3.34 & .983 \\
16 & 104 & 1.00 & 5.00 & 3.32 & .939 \\
17 & 104 & 1.00 & 5.00 & 3.13 & .763 \\
18 & 104 & 2.00 & 5.00 & 3.88 & .804 \\
19 & 104 & 1.00 & 5.00 & 3.78 & .843 \\
20 & 104 & 1.00 & 5.00 & 3.76 & 1.016 \\
\hline
\end{tabular}

For the factor analysis, reliability analysis was performed for each item. As shown in Table 3, Cronbach's Alpha value was .744, which means that the items were statistically significant. In the social science field, reliability is considered to be secured if Cronbach's Alpha value is over .6 (Hair et al., 2010). Of the total 20 items, seventeen items were the crucial ones in extracting factors, so item 6 'It is good to have detailed and clear instructions when the teacher gives homework,' item 10 'I am a little stressed every time I decide what to study and how' and item 13 'I have my own opinion on the progress of the class' were removed to ensure the reliability of the analysis.

TABLE 3

Item Reliability

\begin{tabular}{ccccc}
\hline \hline Item & $\begin{array}{c}\text { Scale Mean } \\
\text { if Item Deleted }\end{array}$ & $\begin{array}{c}\text { Corrected Item- } \\
\text { Total Correlation }\end{array}$ & $\begin{array}{c}\text { Scale Variance } \\
\text { if Item Deleted }\end{array}$ & $\begin{array}{c}\text { Cronbach's Alpha } \\
\text { if Item Deleted }\end{array}$ \\
\hline 1 & 55.40 & .498 & 37.95 & .719 \\
2 & 55.23 & .557 & 38.23 & .717 \\
3 & 55.51 & .319 & 39.43 & .733 \\
4 & 55.75 & .442 & 37.51 & .721 \\
5 & 55.30 & .412 & 38.42 & .725 \\
7 & 55.80 & .596 & 36.19 & .707 \\
8 & 55.28 & .558 & 37.06 & .712 \\
9 & 55.51 & .362 & 38.23 & .729 \\
11 & 55.50 & .196 & 41.18 & .742 \\
12 & 56.17 & .128 & 40.68 & .753 \\
14 & 56.13 & .202 & 40.07 & .744 \\
\hline
\end{tabular}


A Study on the Validity of the English Learning Style Scale for Korean High School Students

\begin{tabular}{|c|c|c|c|c|}
\hline 15 & 55.69 & .205 & 39.90 & .745 \\
\hline 16 & 55.71 & .226 & 39.85 & .742 \\
\hline 17 & 55.90 & .234 & 40.55 & .740 \\
\hline 18 & 55.15 & .247 & 40.24 & .739 \\
\hline 19 & 55.25 & .498 & 37.54 & .717 \\
\hline 20 & 55.26 & .096 & 41.13 & .756 \\
\hline \multicolumn{2}{|c|}{ Cronbach's Alpha } & .744 & & \\
\hline
\end{tabular}

\section{KMO and Bartlett's Test}

The Kaiser-Meyer-Olkin (KMO) value is a measure of the degree to which the correlation between variables is well explained by other variables (Hair et al., 2010). If this value is low, it means that the selection of variables for factor analysis is not valid. In general, it is desirable to select the variables if the KMO value is above .5 and closer to 1 (Hair et al., 2010). As shown in Table 4, the KMO value of this study is .641, which is not very high but can be considered acceptable.

In addition, Bartlett's Test of Sphericity value indicates the suitability of the factor analysis model. The fit of the factor analysis model is judged by the $p$ value (Hair et al., 2010). In this study, the $p$ value is .001 , and the null hypothesis was rejected, proving that the factor analysis is statistically significant.

TABLE 4

KMO and Bartlett's Test

\begin{tabular}{cccc}
\hline \hline $\begin{array}{c}\text { Kaiser-Meyer-Olkin Measure of } \\
\text { Sampling Adequacy }\end{array}$ & \multicolumn{3}{c}{ Bartlett's Test of Sphericity } \\
\hline .641 & 806.251 & 190 & .641 \\
\hline
\end{tabular}

\section{Variance Explained}

The variance explained of each factor is shown in Table 5. The initial eigenvalue represents the amount of variance explained by the factor, and the higher the value is, the more important the factor (Hair et al., 2010). The top five factors account for a total variance of $59.26 \%$. The first factor accounts for $22.94 \%$ of the explained variance and the second factor accounts for $10.85 \%$. The third factor accounts for $9.40 \%$, the fourth factor for $8.42 \%$, and the fifth factor for $7.65 \%$. Eigenvalue is a measure of the variance of each factor. In other words, eigenvalue indicates how much explanatory power each factor has. 
TABLE 5

Total Variance Explained and Scree Plot

\begin{tabular}{|c|c|c|c|c|c|c|}
\hline \multirow{2}{*}{ Component } & \multicolumn{3}{|c|}{ Initial Eigenvalues } & \multicolumn{3}{|c|}{$\begin{array}{l}\text { Rotation Sums of } \\
\text { Squared Loadings }\end{array}$} \\
\hline & Total & $\begin{array}{l}\text { Percent of } \\
\text { Variance }\end{array}$ & $\begin{array}{l}\text { Cumulative } \\
\text { Percent }\end{array}$ & Total & $\begin{array}{l}\text { Percent of } \\
\text { Variance }\end{array}$ & $\begin{array}{l}\text { Cumulative } \\
\text { Percent }\end{array}$ \\
\hline 1 & 4.58 & 22.94 & 22.94 & 3.18 & 15.91 & 15.91 \\
\hline 2 & 2.17 & 10.85 & 33.79 & 2.78 & 13.92 & 29.83 \\
\hline 3 & 1.88 & 9.40 & 43.20 & 1.99 & 9.96 & 39.79 \\
\hline 4 & 1.68 & 8.42 & 51.62 & 1.97 & 9.88 & 49.67 \\
\hline 5 & 1.53 & 7.65 & 59.26 & 1.92 & 9.60 & 59.26 \\
\hline 6 & 1.25 & 6.28 & 65.56 & \multicolumn{3}{|c|}{ Seree Plot } \\
\hline 7 & 1.17 & 5.87 & 71.43 & \multirow{12}{*}{$q$} & & \\
\hline 8 & .83 & 4.18 & 75.62 & & & \\
\hline 9 & .82 & 4.11 & 79.73 & & & \\
\hline 10 & .77 & 3.86 & 83.60 & & & \\
\hline 11 & .53 & 2.69 & 86.29 & & & \\
\hline 12 & .49 & 2.49 & 88.78 & & & \\
\hline 13 & .45 & 2.29 & 91.08 & & & \\
\hline 14 & .38 & 1.93 & 93.00 & & & \\
\hline 15 & .34 & 1.73 & 94.74 & & & \\
\hline 16 & .30 & 1.53 & 96.27 & & & \\
\hline 17 & .22 & 1.14 & 97.42 & & & \\
\hline 18 & .20 & 1.02 & 98.44 & & & \\
\hline 19 & .16 & .84 & 99.28 & \multirow{2}{*}{\multicolumn{3}{|c|}{ 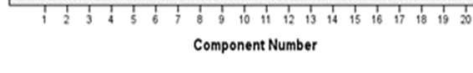 }} \\
\hline 20 & .14 & .71 & 100.00 & & & \\
\hline
\end{tabular}

The eigenvalue used in the factor analysis is usually set to 1 . The higher the eigenvalue is, the larger the proportion of the factor is (Hair et al., 2010). Even though seven factors had 1 or more initial eigenvalues, five factors were chosen for the ratio of explain variance and ease of analysis. The reason for removing the two factors from the first seven factors is that the statistical power, or cumulative percent $(59.26 \%)$ are higher when analyzed by five factors than the seven ones.

\section{Extracted Components}

After five factors were extracted, the newly derived factor matrix was rotated so that each factor could reflect the given variables more clearly as shown in Table 6. As shown in Table 6, factor loading values were analyzed for each variable. The factor loading value represents the degree of correlation between each variable and the factor (Hair et al., 2010). Each variable gathered in factors with high loading. Item 8 of the first factor has the highest loading value (.752), and item 10 of the fifth factor has the lowest value (-.411). Factor loading criteria are generally considered to be .3 or greater, but more stringent criteria are considered to be .4 or .5 or greater. In this study, all factor loading was analyzed based on .5 or higher. 
TABLE 6

Rotated Component Matrix

\begin{tabular}{crrrrr}
\hline \hline \multirow{2}{*}{ Item } & \multicolumn{5}{c}{ Factor } \\
& 1 & 2 & 3 & 4 & 5 \\
\hline 1 & .668 & .399 & .073 & .103 & -.320 \\
2 & .499 & .595 & .257 & .008 & -.202 \\
3 & .197 & .620 & -.093 & -.021 & .052 \\
4 & .271 & .657 & .028 & .034 & .214 \\
5 & .709 & .042 & .331 & -.260 & .190 \\
6 & .366 & .498 & .381 & -.132 & .039 \\
7 & .590 & .140 & .099 & .334 & .280 \\
8 & .752 & .208 & .083 & -.014 & .234 \\
9 & .748 & .031 & -.229 & .214 & -.159 \\
10 & .059 & -.025 & .411 & .093 & -.411 \\
11 & -.103 & .718 & .059 & -.051 & -.090 \\
12 & .094 & -.256 & -.099 & .666 & .351 \\
13 & .155 & .499 & .033 & -.091 & .311 \\
14 & .076 & .071 & -.242 & .213 & .721 \\
15 & .046 & .089 & .240 & -.060 & .665 \\
16 & .144 & -.066 & .076 & .834 & -.153 \\
17 & -.288 & .534 & .170 & .586 & -.005 \\
18 & .086 & .058 & .696 & .184 & -.240 \\
19 & .311 & .056 & .539 & .321 & .283 \\
20 & -.059 & .065 & .692 & -.180 & .111 \\
\hline
\end{tabular}

Based on the contents of the items gathered at each factor, the following five learning styles were conceptualized using terms that describe the characteristics of each factor. The first factor is the class immersion style because the students who participated in the class with a native speaker have a relatively high confidence in their English ability and tend to actively participate and engage in the class based on the confidence. This tendency reflects the fact that students immerge actively the flow of classwork conducted with the native speaker. In other words, the native speaker has relatively higher frequency to give students opportunities to speak, and students become more attentive to the teacher's utterances and instructional processes in order to respond to the opportunities. Students with class immersion style tend to dynamically respond to the tasks presented by the teacher and to solve problems on their own. Item 1, item 5, item 7, item 8 and item 9 gathered as the first factor as shown in Table 7. Second, throughout the class taught by a native speaker, students present their own opinions and perform tasks in a creative and newly way, which is a self-expression style. Native speaker's class focuses on higher tolerance of individual student's utterances and expressions. Students tend to give him or her various opinions and receive positive feedback because the native speaker tends to give value to the speech itself rather than to the evaluation of the correct answer. Students with the self-expression style respond positively to task performance and various evaluation methods that can express their personality. Item 2, item 3, item 4, item 11 and item 17 were collected as the 
second factor.

TABLE 7

Exploratory Factor Analysis

\begin{tabular}{|c|c|c|c|c|c|c|}
\hline Item & 1 & 2 & 3 & 4 & 5 & Factor \\
\hline 8 & 0.752 & & & & & \multirow{5}{*}{ class immersion } \\
\hline 9 & 0.748 & & & & & \\
\hline 5 & 0.709 & & & & & \\
\hline 1 & 0.668 & & & & & \\
\hline 7 & 0.590 & & & & & \\
\hline 11 & & 0.718 & & & & \multirow{5}{*}{ self-expression } \\
\hline 4 & & 0.657 & & & & \\
\hline 3 & & 0.620 & & & & \\
\hline 2 & & 0.595 & & & & \\
\hline 17 & & 0.534 & & & & \\
\hline 18 & & & 0.696 & & & \multirow{3}{*}{ goal recognition } \\
\hline 20 & & & 0.692 & & & \\
\hline 19 & & & 0.539 & & & \\
\hline 16 & & & & 0.834 & & \multirow{2}{*}{ systematic dependence } \\
\hline 12 & & & & 0.666 & & \\
\hline 14 & & & & & 0.721 & \multirow{2}{*}{ information orientation } \\
\hline 15 & & & & & 0.665 & \\
\hline
\end{tabular}

Third, students are relatively clear about the goals of participating in English classes and strive to achieve them, which means the goal recognition style. Students want to have the native speaker expressly summarize the subject and content of the lesson and, if necessary, actively seek to explore the newly set learning goals. Item 18, item 19, item 11 and item 20 clustered in the third factor. Students with the fourth style of learning take the control of the teacher and the systematic operation of the class seriously. A style with this characteristic is called a systematic dependence. Students who have a systematic dependence style expect to be clearly presented information about the assessment system by the teacher. This phenomenon is the result of students' adaptation to existing English classes for a long time, and it is thought that the main reason is the imprint of aiming, teaching, and evaluation procedure emphasized in the traditional English class. Item 12, item 16 were grouped in the fourth factor.

Lastly, Students respond sensitively to the collection and summarization of information throughout the class. Students strive to more accurately record the information provided by a native speaker and seek to enhance the effectiveness of learning by gathering a variety of information related to topics presented. Considering this point, the fifth style can be called information orientation. Item 14 and item 15 were categorized into the fifth factor. 


\section{CONCLUSION AND IMPLICATION}

In this study, principal factor analysis was used to identify the styles of English learning that students in the native speaker's multimedia-based class would continue to have. Based on the positive and new perception that students have about native speaker's teaching, the students had five styles of English learning. Throughout the native speaker's class, students have class immersion style by which they focus actively on the learning procedure with higher self-confidence, self-expression style showing actively their own thoughts and expressions, goal recognition style focusing on selection and performance of clear goals, systematic dependence style expecting clear teaching and assessment system, and information orientation style collecting and using actively information learned in class.

Considering the characteristics of these styles of English learning, it is necessary for a co-teacher of the native speaker or the native speaker to prepare and develop the lesson plan in the following points. First, the teacher needs to prepare various questions in accordance with the topic of the lesson so that the students express their opinions positively, and to provide active feedback to the students' answers promptly. As many students as possible are given opportunities to speak, tolerance for mistakes will be broadened. Second, students should obtain chances to present various types of tasks in creative forms so that they develop their language ability in a variety of ways. In addition, there is a need for reconstruction of textbooks that are designed to express their opinions as much as possible. Third, when preparing the target language lessons, there should be a systematic lesson plan so that students clearly identify their learning goals. The classes conducted only by a native speaker without textbooks are limited in their effectiveness, and the high quality class is expected only when target language classes are equipped with proper formats and systems. Fourth, English teachers need to think about ways in which students can store, disseminate, and deepen information about the English lessons. A worksheet should be developed that enables students to write the essay creatively, and an internet blog or media should be utilized that allows information to be continuously published and stored. Finally, the efforts of a native speaker and a co-teacher are also important for effective teaching. In the case of a native speaker, it is hard to grasp the system of curriculum prepared for each school in depth. That is why it is important for a co-teacher to provide information about the characteristics of the students' learning styles, and to provide feedback on the lesson plan.

This study was conducted with high school students participating in native speaker's English class based on multimedia. However, considering the fact that native speakers are teaching English in many schools nationwide, it is necessary to study the features of the styles of English learning that elementary and middle school students have when participating in native speaker's class. In addition, a variety of research methods, such as 
confirmatory factor analysis and qualitative research, as well as exploratory factor analysis performed in this study, will be effective if they are applied to investigation of native speaker's English class and students taking part in the class.

\section{REFERENCES}

Amthor, G. R. (1991). Interactive multimedia in education: Concepts and technology, trends and model applications, megamedia and knowledge systems. T.H.E. Journal, 19(2), 2-5.

Auerbach, E. R. (1993). Reexamining English only in the ESL classroom. TESOL Quarterly, 27(1), 9-32.

Barker, J., \& Tucker, R. N. (1990). The interactive learning revolution: Multimedia in education and training. London: Kogan Page.

Brown, H. D. (2000). Principles of language learning and teaching. New York, NY: Longman.

Chae, A. (2007). A case study on team teaching between Korean and native teachers in Korean middle school English classroom (Unpublished master's thesis). Konkuk University, Seoul.

Cho, C. (2001). Secondary school students' English language learning strategies: Focusing on personality, learning styles, and internet use. Studies in English Education, 6(2), 179-218.

Choi, S., Kim, S., \& Kim, I. (2006). English education and the information age. English Language \& Literature Teaching, 12(1), 245-246.

Chun, S. (2015). Native English-speaking teachers and Korean English teachers: A qualitative analysis of Korean university students' beliefs. Studies in Foreign Language Education, 29(3), 181-203.

Davey, D., Jones, K. G., \& Fox, J. (1995). Multimedia for language learning: Some course design issues. Computer Assisted Language Learning, 8(1), 31-44.

Gayeski, D. (1993). Multimedia for learning. Englewood Cliffs, NJ: Educational Technology Publications.

Hair, J. F., Black, W. C., Babin, B. J., \& Anderson, R. E. (2010). Multivariate data analysis. New Brunswick, NJ: Pearson Education.

Heinich, R., Molenda, M., Russell, J. D., \& Smaldino, S. E. (1996). Instructional media and technologies for learning. Upper Saddle River, NJ: Prentice Hall.

Kim, B., Kang, M., \& Yoon, S. (2013). A study of learners' motivation and anxiety in coteaching class. Secondary English Education, 7(2), 49-78. 
Kim, C. (2010). A study on the effects of native English teacher's teaching in the middle school. Modern Studies in English Language \& Literature, 54(3), 39-65.

Kim, S. (2001). A study on the design and the use of multimedia contents for effective English language teaching and learning. Multimedia-Assisted Language Learning, 4(2), 99-119.

Kim, Y., \& Jeong, S. (2008). A study on the effect and the preference of the English class by native English speaking instructor: Focused on the students related to the hospitality in college and university. International Journal of Tourism Management and Sciences, 23(2), 56-79.

Kolb, D. A. (2007). Kolb learning style inventory. Boston, MA: Experience Based Learning Systems.

Lee, C. H. (1997). The use of media technology in foreign language teaching and learning at university level: A study of teachers' attitudes in Korea (Unpublished doctoral dissertation). University of Newcastle, Newcastle upon Tyne.

Lee, M., \& Seong, G. (2011). A native English-speaking teacher's and a Korean teacher's roles in the co-teaching classroom. Journal of Education \& Culture, 17(1), 225-260.

$\mathrm{Li}$, J. (2005). On the teaching characteristics of foreign teachers and management of foreign teachers' teaching. Journal of Guangxi University, 27, 59-61.

Liu, M., \& Reed, W. M. (1995). The effect of hypermedia assisted instruction on second language learning. Journal of Educational Computing Research, 12(2), 159-175.

Looms, P. O. (1993). Interactive multimedia in education. In C. Latchem, J. Williamson, \& L. Henderson-Lancett (Eds.), Interactive multimedia (pp. 115-134). London: Kogan Page.

Min, C., Kim, J., Rha, K., \& Kang, H. (2014). Setting up assessment indicators for analyzing the effectiveness of the native English teacher policy of Korea English teacher training institutes. The Journal of Korea Elementary Education, 25(3), 93110.

Park, E. (2011). A study of Korean elementary and middle school students' satisfaction about English classes taught by native speakers of English. Modern Studies in English Language \& Literature, 55(4), 91-110.

Perzylo, L. (1993). The application of multimedia CD-ROMs in schools. British Journal of Educational Technology, 24(3), 191-197.

Rosenthal, A. S., \& Robert, A. S. (1984). A communicative approach to foreign language instruction: The UMBC projects. Foreign Language Annals, 20(3), 245-253.

Ryu, S. (2003). The effects of team teaching with a native English teacher on the affective domain of elementary school students (Unpublished master's thesis). Konkuk University, Seoul.

Shim, J., Lee, H., \& Eom, M. (2016). The study of high school students' satisfaction with 
their native speaker teacher. The Linguistic Association of Korea Journal, 24(1), 95 112.

Yeon, J. (1996). An effective teaching to improve communicative proficiency through cooperative instruction between ENL/RL teachers. English Language \& Literature Teaching, 2(3), 56-80.

\section{APPENDIX}

Instrument for English Learning Styles

- 문항은 총 20 개로 구성되어 있습니다.

\begin{tabular}{|c|c|c|c|c|c|c|}
\hline \multirow[b]{2}{*}{ 번호 } & \multirow[b]{2}{*}{ 질 문 내 용 } & \multicolumn{5}{|c|}{ 선택지( $V$ 표 ) } \\
\hline & & \begin{tabular}{|l} 
전혀 \\
그렿지 \\
않다
\end{tabular} & $\begin{array}{l}\text { 그령지 } \\
\text { 않다 }\end{array}$ & 봉통 & 그렇다 & $\begin{array}{l}\text { 애우 } \\
\text { 그렇다 }\end{array}$ \\
\hline 1 & $\begin{array}{l}\text { 나는 다른 사람 도움 없이 혼자 힘으로 숙제를 하는 것을 좋 } \\
\text { 아한다. }\end{array}$ & & & & & \\
\hline 2 & $\begin{array}{l}\text { 나는 섯새ㄴㅣㅣㅇㅣ 수업을 통해 합생들에게 기대하는 것이 무엇 } \\
\text { 인치 정확하게 이야기후길 바란다. }\end{array}$ & & & & & \\
\hline 3 & $\begin{array}{l}\text { 나는 학슽 내용에 대한 나의 개인적인 의견이 교과서만큼 좋 } \\
\text { 다고 상한다. }\end{array}$ & & & & & \\
\hline 4 & 나는 학습 내용의 중요도를 판단할 때 선생님에게 물어본다. & & & & & \\
\hline 5 & 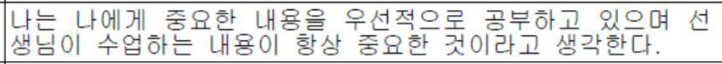 & & & & & \\
\hline 6 & $\begin{array}{l}\text { 선생님이 숙제를 주실 때 세부적이고 분명한 지시사항이 있 } \\
\text { 으면 좋다. }\end{array}$ & & & & & \\
\hline 7 & 나는 스스로의 힘으로 수업 시간에 많은 것을 배운다. & & & & & \\
\hline 8 & 나는 선생님의 지시사항을 정확하게 준수하여 숙제를 한다. & & & & & \\
\hline 9 & 나는 나의 능력에 자신감을 느낀다. & & & & & \\
\hline 10 & $\begin{array}{l}\text { 무엇을 어떻게 공부해야 할지 결정할 때마다 약간 스트레스 } \\
\text { 받는다. }\end{array}$ & & & & & \\
\hline 11 & $\begin{array}{l}\text { 나는 수업 과정에서 나 자신만의 의견을 만들어내는 것을 좋 } \\
\text { 아한다. }\end{array}$ & & & & & \\
\hline 12 & 학생들은 수업 시간에 교사에 의해서 통제받는 것이 좋다. & & & & & \\
\hline 13 & 나는 수업의 진행에 대한 나 자신만의 의견을 갖고 있다. & & & & & \\
\hline 14 & 나의 노트에는 모든 수업 내용이 들어 있다. & & & & & \\
\hline 15 & 나는 수업 주제가 좋으면 스스로 더 많은 정보를 찾아본다. & & & & & \\
\hline 16 & 나는 고도로 조직적이고 체계화된 수업을 좋아한다. & & & & & \\
\hline 17 & 나는 나 스스로 프로젝트를 수행하는 것을 좋아한다. & & & & & \\
\hline 18 & $\begin{array}{l}\text { 학생들은 시험에 출제되는 내용이 무엇인지에 대해서 정확하 } \\
\text { 게 전달아야 한다. }\end{array}$ & & & & & \\
\hline 19 & $\begin{array}{l}\text { 나는 이해가 잘 되지 않는 부분을 스스로 이해해보려고 노력 } \\
\text { 한다. }\end{array}$ & & & & & \\
\hline 20 & 나는 선생님이 칠판에 수업 내용을 요의 & & & & & \\
\hline
\end{tabular}


A Study on the Validity of the English Learning Style Scale for Korean High School Students in a Native Teacher's Class Based on Multimedia

Applicable level: secondary

Keywords: English native speaker, multimedia-based teaching, learning style, factor analysis

Kim, Nayu ( $1^{\text {st }}$ author)

The Department of English Education

Chonbuk National University

567 Baekje-daero, Deokjin-gu

Jeonju-si, Jeollabuk-do, 54896, Korea

E-mail: kimnayu98@naver.com

Lee, Heechul (Corresponding author)

The Department of English Education

Chonbuk National University

567 Baekje-daero, Deokjin-gu

Jeonju-si, Jeollabuk-do, 54896, Korea

E-mail: hclee@chonbuk.ac.kr

Received: September 28, 2018

Revised version: November 8, 2018

Accepted: November 25, 2018 